\title{
Decision time for Europe's hot rock project
}

Paris. Geothermal energy research in Europe faces a make-or-break point next month, when participants in the European Hot Dry Rock (HDR) project are schedulcd to decide whether to build a prototype plant for electricity production at Soultz-sousForêts near Strasbourg, in France, or to abandon the research altogether.

Building the pilot plant would require around ECU37.5 million (US\$50 million) over five years from the project's backers, France, Germany and the European Commission. The decision whether to proceed will be taken after two separate reviews of the programme requested by the commission and the French ministry of industry.

The reviews are focusing on the economics of the high-technology 'closed-circuit' geothermal energy systems being developed at Soultz-sous-Forêts. Cost-effectiveness is the main barrier to developing the technology, with costs depending on factors such as borehole depth, the steepness of the temperature gradient with depth, and the ease of pumping water through the rock.

Long-term economic prospects depend also on obtaining a large enough heat transfer surface underground - for example, by exploiting natural fractures in the rock -

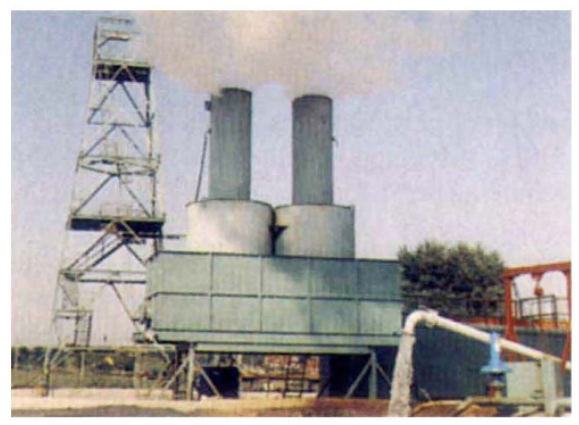

Full steam ahead? Experimental facility may be developed into a prototype geothermal reactor.

and on the number of years that a site can be worked before the rock cools down.

From a technical point of view, however, it seems generally accepted that the closedcircuit systems, in which water is injected into rocks that do not normally support water-flow and recovered as steam, offer a path to much wider exploitation of geothermal energy. At present this is restricted to areas with natural sources of steam, such as the Philippines, which produces around onefifth of its electricity this way.

Roy Baria, a scientist with HDR, is optimistic that the reviews will be positive. In

\section{Renewable energy regains its funding}

\begin{abstract}
Munich. Europe's research commissioner, Edith Cresson, last week countered allegations that the European Commission had redirected money intended for renewable energy research projects to mainstream energy projects by agreeing to release sufficient funds to make up the balance between the two areas.

But she did not explicitly concede that the commission had been at fault in the way that it has administered funding of the five-year Joule programme into nonnuclear energy, which has a total budget of ECU967 million (US\$1.3 billion).

In the summer, the commission came under fire from the European Parliament after allocating only 40 per cent of the funds for Joule's first funding round, worth ECU191 million, to renewable energy projects, despite a parliamentary decision that such projects should receive 60 per cent of the total funds (see Nature 376, 628; 1995). At the time, commission officials said they had not received enough strong applications in the area of renewable energy, and that the balance would be made up in future rounds.
\end{abstract}

An investigation by a parliamentary committee subsequently revealed that a senior commission official had overridden expert evaluations of some projects. While accepting that the commission has the right to make such changes, the committee asked for a clarification of the grounds on which these decisions had been made, and complained that the commission had applied procedures that were not 'transparent'.

In replying to the allegations last week, Cresson said the commission remained committed to the rules agreed with parliament for the allocation of the Joule funds. She said a reserve list of projects submitted in the first round, giving priority to renewable energy projects and worth a minimum of ECU10 million, would be immediately drawn up. At least part of a programme's reserve list is usually funded.

Cresson also said the commission will put out a special call for proposals early next year. It will be aimed at renewable energy projects, with priority for solar energy, in order to make good the shortfall in funded projects.

Nuala Ahern, a member of the European Parliament who was closely involved in the investigation, says that parliament has accepted the response of the commission. "But we will continue to keep a close eye on how the commission operates," she says. Alison Abbott particular, the project team, which has drilled $4 \mathrm{~km}$ into granite at Soultz, is confident of producing electricity in a pilot 10 MW plant at less than the critical threshold of ECU0.12 per $\mathrm{kW}$ hour.

Moreover, experiments carried out this summer suggest that the major technical difficulty of recovering all the injected water has been solved, according to Philippe Chartier, the scientific director of the French national environment and energy agency (ADEME), which is taking part in the programme.

But at least one European country is likely to be sceptical. Last year, the United Kingdom abandoned its domestic geothermal energy project in Cornwall, on which it had spent $£ 40$ million over two decades, following a review by the Department of Trade and Industry (DTI).

Britain also withdrew from the European HDR project last year after a review of its overall renewable energy research. According to one DTI official, the department believes that HDR is neither technically nor economically feasible in the UK in the foreseeable future. "We exhausted all the technical possibilities," he says, adding that the UK does not intend to reconsider its participation in the European HDR project.

But John Garnish, a European Commission official involved in HDR, argues that the DTI review was unfair, claiming that the department assessed the Cornwall project on the grounds of economics rather than as a research programme on 'rock mechanics'.

Garnish says he is reasonably optimistic that next month's decision will be positive, adding that the outcome will be critical for the future of geothermal energy in Europe. $\mathrm{He}$ points out that the technology is now mature, and that in the absence of a decision to pursue commercial development, there is unlikely to be support for further research.

The Soultz-sous-Forêts facility has a major advantage, in that the rock is much more fractured than the sites tested previously in the United Kingdom and the United States, making the project there technically easier and more efficient. But this feature is also a drawback, admits Charticr, as it limits the relevance of results obtained at the site to rock with similar properties, which, although common worldwide, are less abundant than rocks having few fractures. The Soultz programme is a "halfway step" towards the goal of wide exploitation of geothermal energy, says Chartier. "It's an apprenticeship."

If the participants approve the programme, building of the prototype would begin next year, and management handed over in 1998 to a consortium of utility companies, including EDF (France), Pfalzwerk (Germany) and ENEL (Italy), according to programme officials.

Declan Butler 